\title{
Study on the Post Practice Operational Mechanism of Higher Vocational College Tourism Majors Based on the Modern Apprenticeship System
}

\author{
Ling Xu
}

Suzhou Institute of Trade and Commerce, Suzhou Jiangsu, 215009, China

Keywords: Modern apprenticeship system, Higher vocational college, Tourism major, Post practice.

\begin{abstract}
The manner and purpose of the modern apprenticeship system are improving the students' comprehensive quality and practical ability as well as further the students' ability to work so as to shorten the time of employment. It is the direction and trend of higher education development in China to integrate the modern apprenticeship system into the vocational colleges' post practice. Based on this, this paper analyzes the operational mechanism of using the apprentice system in the post practice of the higher vocational college by taking the tourism major of higher vocational college as the object of study. Besides, the paper studies the basic effect of the apprenticeship system of post practice of tourism major in higher vocational college and finally puts forward some feasible suggestions.
\end{abstract}

\section{Introduction}

In the current higher vocational college education, an effective integration of apprenticeships system and post practice is a major reform of modern education. With the students as the center, the combination of traditional apprenticeship model with modern higher vocational college education is the development product of current vocational education. On the basis of modern apprenticeship talents training, transition and connection from theory and practice can not only cultivate the students' theoretical learning ability but also the students' vocational skills. In this model, it relies on the school's theoretical base, and then has post practice with the relationship between schools and enterprises, establishes a model which takes the "master" in the enterprises as the center so as to teach students work skills and experiences. This stereo culture method is an important way of education in higher vocational colleges at present.

The development of the modern apprenticeship system has been linked to the reform of education in higher vocational colleges. It is necessary to introduce modern apprenticeship system and cultivate the interdisciplinary talents in the post practice of higher vocational colleges. Our country's tourism industry's booming brings a lot of jobs and talents demand. However, many vocational colleges in China have a more traditional way of cultivating tourism professionals without taking specific talents demand characteristics into account.Thus, in the process of talents cultivation, it has deviations especially during the post practice process. Therefore, it is an important model reform of higher vocational college tourism professionals training by combining post practice with modern apprenticeship system.

\section{Related theoretical overview}

\section{Modern apprenticeship system}

"Apprenticeship" is an old professional education form. The teaching process of vocational skills mainly occurs in the production and labor process. In vocational schools, such "master" teaching students skills, experience and culture lasts for thousands of years. The modern apprenticeship system 
is developed in the traditional apprenticeship system, which is the result of the cognition and learning of modern theory of the traditional system by using the modern perspective. The modern apprenticeship system trains students' vocational skills through modern teaching theory in the way of masters and apprentices. This not only can cultivate students' basic theoretical knowledge, but also cultivate students' vocational skills. In teaching mode, the modern apprenticeship system adopts a more traditional model teaching method, which is to teach students how to do it first and then start to train a lot.

In terms of form, the modern apprenticeship system conforms to the characteristics of education in higher vocational colleges in our country, which is also the most needed mode for vocational colleges to train talents. Therefore, combining the modern apprenticeship system with the teaching of higher vocational colleges and the practice can not only carry out the academic education but also the development of technology. Therefore, "modern apprenticeship system" fundamentally makes higher vocational college education take on the task of cultivating high-skilled talents with higher theoretical level and innovative practice ability.

\section{Post practice}

Post practice is a common practice. Generally, students in universities or higher vocational colleges should have an internship before graduation. This kind of practice includes taking a post practice. Different with other internships, post practice requires students be able to independently undertake post responsibilities and finish work tasks, for undergraduate students, this is a great challenge as well as a very effective training process.It can not only train students' professional skills. At the same time, it can effectively improve students' language organization ability, social judgment ability, comprehensive skills and character quality.

\section{The role of modern apprenticeship in the post practice}

The modern apprenticeship system focuses on the advantages of the current higher vocational colleges education and traditional education. After reasonable transformation, it makes theory and practice unified together. The modern apprenticeship system focuses on the learning experience of skills. What it needs is one continuation of technology so as to promote the development of self-correcting and self-monitoring skills.

The biggest obstacle for students in the internship is the lack of practical experience. Although there are many theories in the school, the understanding of enterprises is everything starts with "zero". In post practice, the intern will be in the real job for a long time, the fastest way to take knowledge in this mode is guidance from the "master". The way of learning while working can let interns get more knowledge and make practical use of it. With master's help, students' ability to correct error can be greatly improved. Besides, it also plays an extremely important role for students to apply the professional knowledge acquired at school into actual work. This kind of targeted education way that studying in the work while also working in the study, is the way the higher vocational colleges need as well as an important way for enterprises to acquire talents. Therefore, the application of modern mentoring system in post practice is an important way for students, schools and enterprises.

\section{The operation mechanism of modern apprenticeship system in post practice of tourism major in higher vocational colleges}

\section{Operational mode}

According to the talents needs of tourism enterprises and training requirements of higher vocational colleges, higher vocational college tourism major and tourism enterprises altogether determine the cultivation mode of talents and carry out the development of the post practice. From the survey, the school use the model of cooperation with tourism enterprises to transfer students to the actual post of tourism enterprises for training, the enterprises sign the training agreement with the school, at the same time, develop the training courses and evaluation solutions of post practice altogether. 
At present, the tourism major of higher vocational college is engaged in deep cooperation with various travel agencies and hotels, using the operation interval of tourism enterprises to have post practice cultivation by adopting the way of off-season internship and in season classes for the post practice of students of tourism management major. For the post practice of students major in tourism management requires, students are usually required to study and circulate in their jobs and on campus, they need to complete the theoretical courses in the school before entering the specific work in tourism enterprises. This kind of way of cultivation by the company and school together requires a combination of the professional theoretical teaching and the profession skills cultivation of tourism enterprises, realizing the model of co-culture between enterprise and school, the basic model is as follows.

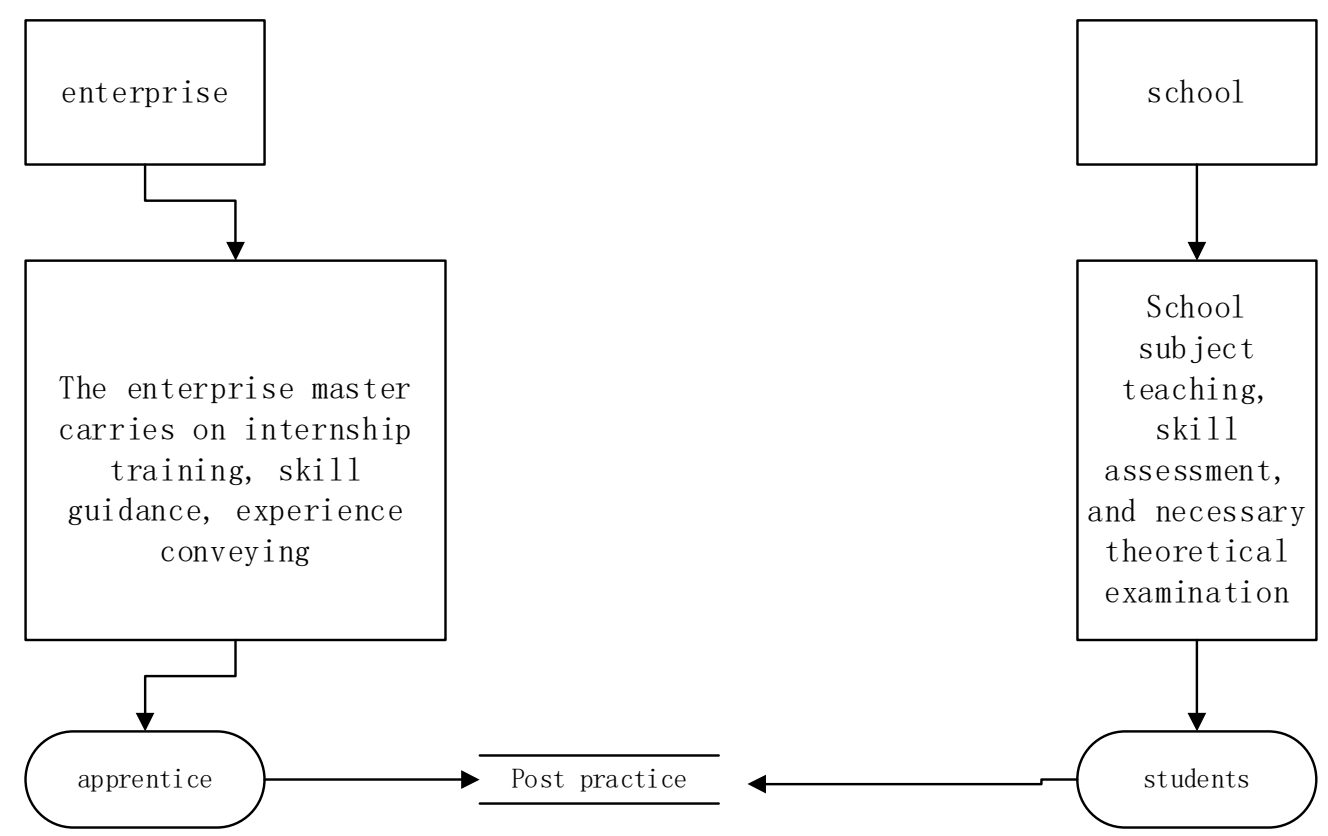

Fig. 1. The operational mechanism of the post practice between schools and enterprises

\section{Curriculum system}

At present, the "master" of the modern apprenticeship system requires not only that the students of post practice adapt to the formal job, but also solve the problems and things that are encountered in the job. In this case, the distance between professional teaching and professional standards can be found. From the survey, it is found that except working for half a year, students of higher vocational colleges will also need to complete the basic theory exam in the school curriculum and complete the necessary class scores so as to complete the streamlined culture mode from post cognition to post practice.

\section{Assessment mode}

The objective of vocational college tourism major is not only to complete the content of internship, but also to require students to form a unified assessment requirements according to the training mode of modern apprenticeship, to have assessment on professional courses and job skills so as to realize the goal of unification of education and practice.

(1) Combination of process assessment and result assessment

First, process assessment. Process assessment is the assessment between the "master" and "apprentice" in the tourism enterprises. The basic workflow of the post practice is to: see the master do -- learn to do -- practice -- review. This method requires able to learn while practicing in the post practice, effectively integrate the skills and experience of the master to realize the best aim of the post practice. Finally, the master will conduct a grade assessment on students' post practice.

Second, result assessment. The result assessment is the assessment of the job requirements of the students in the post practice. According to the standard of the school, students should not only complete the skills learning requirements during the internship, but also complete the school's theoretical courses learning and finally conduct the results assessment. According to the practice and 
theory required goal of the modern apprenticeship system, the results assessments of the post practice should include vocational skills examination, theoretical study assessment and emotional attitude assessment. The accounts are 50\%, 40\%, 10\%, respectively. The course assessment results are weighted average of process assessment and result assessment, and the weight of process assessment and result assessment is 6:4.

(2) The combination of vocational qualification and course assessment

The basis of the process assessment and the result assessment, one is taking the vocational skill requirements of enterprise to the employees as the standard, the other is taking standard according to the hotel industry professional qualification as criterion.

The effect of implementing the post practice mode based on the modern apprenticeship system

\section{A great improvement in literacy}

In post practice, Students study and work in the way of staff in enterprises. They change their various ideas at students age. At the same time,they change from daring not speak to have warm greetings and communication with customers, and in this case the students gradually form the good habits of grooming and courtesy manners.

A clear improvement in consciousness

In learning, since it can't arrange the actual scene for service to the customer, this makes the service ability of students can't get real ascension, it is very deadly for students major in tourism. Therefore, post practice combines good customer base and with the guidance of "master" from the side, students improve their service ability.

Skills improved greatly

After the apprenticeship system, students can both work and study in the field of post practice, learn while working, they can consolidate the knowledge acquired. This combination of work and learning enables students to combine theory with professional skills, thus forming a better internship effect.

\section{Some Suggestions on the application of modern apprenticeship system in higher vocational college tourism majors}

\section{Inviting enterprises to work together to develop a plan for the post practice}

Modern apprenticeship system is not only a modern practice mode, but also can make corresponding adaptation plan which can be formulated by school as well as tourism enterprises. But based on better practice purpose, the author suggests that schools and enterprises should jointly develop an internship programme. In general terms, schools lay emphasis on theory, while enterprises lay emphasis on practical professional skill operation. Therefore, when they have different priorities, theory and practice need to be effectively integrated to form a post practice solution based on apprenticeship system suitable for current market economy.

\section{Promoting the top teacher guidance system of post practice}

Although students as the main body of modern apprenticeship system, it can be seen that the "master" of the enterprise is also an important participant, so examining on the "master" of the enterprise is also very necessary. It is recommended to carry out the "master" ranking and competition plan, form ranking mechanism in tourism enterprises cooperated with the school. The top "masters" can get material and spiritual rewards. This can not only mobilize the enthusiasm of "master", but also promote and push students in post practice.

\section{Standardizing the management system of post practice}

First the amendatory post practice management system is an important basis for students to have smooth internship. According to the modern apprenticeship model, it is required to carry out multi-level internship management style to construct a scientific management system for post practice. This multi-level management system is to divide the interns into groups and then arrange 
them to enter different departments of the tourism enterprise. Then the post practice solution will be planned with the enterprise to make enterprise take macro control of students. Different types of internship task book should be done to make reasonable internship procedures. On this basis, the company shall assign a suitable "master" to be responsible for the training of a student, and conduct regular sampling and evaluation of the internship.

Second, "master" and students during the internship are given a fixed time reporting system, and the weekly report system is planned.At the same time, in this situation, the interns should communicate with the teachers in the school, and report the internship situation to the teachers. At the same time, school teachers need to keep in touch and communicate with the "master" of the company where students practice to ask about the students' internship, timely and comprehensively control the students' information during the internship and choose an internship group leader among the students as liaison to communicate the relevant information of both sides of the school and the company.

Finally, implementing student assessment system of post practice, ensuring the students have plenty of theoretical knowledge before post practice, and at the same time, in the internship, carrying out inspection and examination during the student internship process to ensure that students can practice in accordance with the formulated post practice solution to let students clear the job requirements of their posts. The student's weekly and internship reports should be checked according to the requirements, the internship reports need to be reviewed and signed by the three parties-"master", enterprises and teachers. Finally, coming to an internship result.

In a word, the post practice of students of tourism major in higher vocational colleges in our country needs a strict memory. The students' post practice should be strictly controlled combined with modern apprentice system to let the students truly acquire knowledge and ability in practice.

\section{Acknowledgement}

Topic name: The achievement of School-level Major Teaching and Research Project Study on the long-term mechanism of graduation practice-taking tourism major as an example of Suzhou Economic and Trade Vocational and Technical College, Topic number: JY1214.

\section{References}

[1] Zhang Di. A study on the implementation condition of modern apprenticeship in the internship of education professional education, Occupational education study, 2013, 11:136-137.

[2] Yang jie, Hechang Hai. The practice study of the modern apprenticeship in the post practice of building decorative profession, Journal of science and education(the first ten day of a month), 2014,01:555-56.

[3] Zhou Songbing. Research on the post practice model based on modern apprenticeship system, Industry and technology BBS, 2014, 03:253-254.

[4] Chen Zhuo, Huang Xiang Gou. The division of the post practice rights and liabilities of construction engineering technology major under modern apprenticeship system model, Journal of Hubei vocational and technical college, 2012, 03:37-40. 